\title{
HpaP Sequesters HrpJ, an Essential Component of Ralstonia solanacearum Virulence That Triggers Necrosis in Arabidopsis
}

\author{
Fabien Lonjon, ${ }^{1}$ David Rengel, ${ }^{1}$ Fabrice Roux, ${ }^{1}$ Céline Henry, ${ }^{2}$ Marie Turner, ${ }^{1}$ Aurélie Le Ru, ${ }^{3}$ \\ Narjes Razavi, ${ }^{1}$ Cyrus Raja Rubenstein Sabbagh, ${ }^{1}$ Stéphane Genin, ${ }^{1}$ and Fabienne Vailleau ${ }^{1+\dagger}$ \\ ${ }^{1}$ LIPM, Université de Toulouse, INRA, CNRS, Castanet-Tolosan, France \\ ${ }^{2}$ Micalis Institute, PAPPSO, INRA, AgroParisTech, Université Paris-Saclay, 78350 Jouy-en-Josas, France \\ ${ }^{3}$ Research Federation "Agrobiosciences, Interactions et Biodiversité" Castanet-Tolosan, France
}

Accepted 28 September 2019.

\begin{abstract}
The Gram-negative bacterium Ralstonia solanacearum, the causal agent of bacterial wilt, is a worldwide major crop pathogen whose virulence strongly relies on a type III secretion system (T3SS). This extracellular apparatus allows the translocation of proteins, called type III effectors (T3Es), directly into the host cells. To date, very few data are available in plantpathogenic bacteria concerning the role played by type III secretion (T3S) regulators at the posttranslational level. We have demonstrated that HpaP, a putative T3S substrate specificity switch protein of $R$. solanacearum, controls T3E secretion. To better understand the role of HpaP on T3S control, we analyzed the secretomes of the GMI1000 wild-type strain as well as the hpaP mutant using a mass spectrometry experiment (liquid chromatography tandem mass spectrometry). The secretomes of both strains appeared to be very similar and highlighted the modulation of the secretion of few type III substrates. Interestingly, only one type III-associated protein, HrpJ, was identified as specifically secreted by the hpaP mutant. HrpJ appeared to be an essential component of the T3SS, essential for T3S and pathogenicity. We further showed that HrpJ is
\end{abstract}

Current address of F. Lonjon: Department of Cell \& Systems Biology, University of Toronto, Ontario, Canada.

Current address of D. Rengel: Institut de Pharmacologie et Biologie Structurale, IPBS, Université de Toulouse, CNRS, UPS, Toulouse, France.

Current address of M. Turner: Vegenov, BBV, Pen Ar Prat 29250 Saint Pol de Léon, France.

${ }^{\dagger}$ Corresponding author: F. Vailleau; fabienne.vailleau@inra.fr

Funding: This work was supported by the "Laboratoire d'Excellence (LABEX)" TULIP (ANR-10-LABX-41). F. Lonjon was funded by a grant from the French Ministry of National Education and Research, C. R. R. Sabbagh was funded by grants from Lebanon ("Municipalité de Nabatieh" and "Association de Spécialisation et d'Orientation Scientifique"), F. Vailleau was supported by INRA Plant Health and Environment division (SPE) and a French Agence Nationale de la Recherche grant (ANR-2010JCJC-1710-01), and N. Razavi benefited from a Ph.D. grant co-financed by the Occitanie Regional Council and the INRA Plant Health and Environment division (SPE).

*The $\boldsymbol{e}$-Xtra logo stands for "electronic extra" and indicates that eight supplementary figures and seven supplementary tables are published online.

The author(s) declare no conflict of interest.

๑) 2020 The American Phytopathological Society specifically translocated in planta by the hpaP mutant and that HrpJ can physically interact with HpaP. Moreover, confocal microscopy experiments demonstrated a cytoplasmic localization for HrpJ once in planta. When injected into Arabidopsis thaliana leaves, HrpJ is able to trigger a necrosis on 16 natural accessions. A genome-wide association mapping revealed a major association peak with 12 highly significant singlenucleotide polymorphisms located on a plant acyl-transferase.

Keywords: Arabidopsis thaliana, bacterial pathogenesis, effectors, genome-wide association mapping, plant responses to pathogens, proteomics, Ralstonia solanacearum, secretome, type III secretion control

Bacteria have developed various secretion systems to actively release substrates from their cytoplasm to other compartments of the cell, or extracellularly in either other bacteria, eukaryotic cells, or the environment (Costa et al. 2015; Desvaux et al. 2009; Green and Mecsas 2016). Hence, bacteria have developed numerous ways for substrate export, which involve the assistance of secretion systems. Some secretion systems are found in almost all bacteria and secrete a wide variety of substrates, while others have been identified in only a small number of bacterial species and are dedicated to the delivery of only one or few substrates (Green and Mecsas 2016). For the latter category of secretion systems, the type III secretion system (T3SS) is one of the most studied (Büttner 2012). T3SSs correspond to highly complex and conserved nanomachines and constitute a major determinant for virulence of numerous Gram-negative bacteria, including animal-pathogenic bacteria such as Escherichia coli, Salmonella spp., and Shigella spp., as well as devastating plant-pathogenic bacteria such as Pseudomonas syringae, Xanthomonas spp., and Ralstonia solanacearum (Galán et al. 2014; Hu et al. 2017; Hueck 1998). T3SSs are composed of 25 to 30 components, which are evolutionarily related to flagella, and many substructures involved in their assembly are very conserved (Galán et al. 2014; Macnab 2003). These major substructures are (i) a cytoplasmic ATPase complex, (ii) a cytoplasmic ring, (iii) an inner membrane export apparatus, (iv) a basal body (composed of highly oligomerized concentric rings spanning inner and outer bacterial membranes, presumably encircling an inner rod protein), (v) an extracellular needle/pilus, and (vi) a translocon (Büttner 2012; Deng et al. 2017). In phytopathogenic bacteria, these core components are encoded by genes located on the 
hypersensitive response and pathogenicity (hrp) gene cluster. Once assembled, the T3SS spans three cellular membranes (i.e., the bacterial inner and outer membranes and the plant plasma membrane) and the plant cell wall, to allow the injection of bacterial proteins inside the host, called type III effectors (T3Es) (Büttner 2012). The primary function of T3Es is to hijack plant defenses and allow bacterial disease development by suppressing plant immunity as well as interfering with plant hormone regulations, plant metabolism, or plant cellular functions (Büttner 2016; Macho 2016). Alternatively, T3Es can be directly or indirectly recognized by plant resistance proteins, or can activate resistance gene expression leading to plant resistance (Khan et al. 2016). The number of T3Es injected by a bacterium is highly variable. Animal-pathogenic bacteria such as Yersinia pestis usually possess fewer than 10 T3Es (Cornelis et al. 1998; Matsumoto and Young 2009). In contrast, phytopathogenic bacteria inject many more T3Es; for example, $P$. syringae (30 to 40 T3Es) (Dillon et al. 2019) and Xanthomonas spp. (approximately 40 T3Es) (Roux et al. 2015). Interestingly, the vascular soilborne pathogen $R$. solanacearum, agent of bacterial wilt disease, which causes tremendous yield losses worldwide, attacking more than 250 plant species (Genin 2010), possesses a huge arsenal of T3Es (50 to 80 T3Es; 72 T3Es in the model strain GMI1000) (Peeters et al. 2013a).

The T3Es constitute one of the main weapons of Gramnegative bacteria pathogenicity, and their type III secretion (T3S) appears thinly controlled. In animal- and plantpathogenic bacteria, T3S is mainly regulated by two families of proteins, the type III chaperones (T3Cs) and the T3S substrate specificity switch (T3S4) proteins (Büttner 2012; Büttner and He 2009; Izoré et al. 2011; Lohou et al. 2013). These proteins regulate $\mathrm{T} 3 \mathrm{~S}$ at posttranscriptional and posttranslational levels. T3Cs are small, acidic, and cytoplasmic proteins (Büttner 2012; Feldman and Cornelis 2003; Lohou et al. 2013). They can interact directly with T3Es and modulate the secretion of one (class IA chaperones) or several (class IB chaperones) substrates. Other T3Cs (class II chaperones) can interact with translocon proteins (Parsot et al. 2003). In $R$. solanacearum, we previously identified and characterized two class IB chaperones, HpaB and HpaD (Lonjon et al. 2016, 2017). A secretome analysis allowed us to show that $\mathrm{HpaB}$ is required for the secretion of the majority of the T3Es, whereas HpaD is involved in the control of the secretion of few T3Es. Moreover, $\mathrm{HpaB}$ and $\mathrm{HpaD}$ interact with several T3Es and share common interactors but have also specific partners (Lonjon et al. 2016, 2017). The T3S4 family member proteins do not share sequence homology, except a structurally conserved C-terminal domain called the T3S4 domain. T3S4 proteins are involved in the substrate specificity switch of the T3S, from early substrates (corresponding to structural elements of the T3SS) to intermediate and late substrates (corresponding to translocon proteins and T3Es) (Agrain et al. 2005; Lonjon et al. 2016). T3S4 proteins interact with the cytoplasmic regions of members of the YscU family, structural components of the T3SS export apparatus. The cytoplasmic region of YscU family members is autoproteolytically cleaved between the asparagine and proline residues of a conserved NPTH amino acid motif. This cleavage induces a conformational change in the cytoplasmic region of YscU family members and initiates the T3S4 upon binding of the T3S4 protein (Edqvist et al. 2003; Lorenz and Büttner 2011; Zarivach et al. 2008). In animal-pathogenic bacteria, T3S4 proteins are also involved in the control of the length of the needle of the T3SS (Erhardt et al. 2011; Journet et al. 2003) and are now considered to be key components for the establishment of a hierarchy of secretion (Büttner 2012; Deng et al. 2017). On the other hand, in phytopathogenic bacteria, the function of T3S4 proteins remains unclear. The T3S4 family members characterized thus far are HpaC from Xanthomonas campestris pv. vesicatoria, HrpP from $P$. syringae pv. tomato, and $\mathrm{HpaP}$ from $R$. solanacearum. $\mathrm{HpaC}$ is not secreted and has been demonstrated to be important for the secretion of T3Es and translocon proteins and interacts with $\mathrm{HrcU}$ (a member of YscU family) (Büttner et al. 2006; Lorenz and Büttner 2011; Lorenz et al. 2008). HrpP of P. syringae is a T3SS substrate translocated into plant cells and is essential for the function of the T3SS (Morello and Collmer 2009).

In our previous work, we showed that (i) the T3S4 domain of $R$. solanacearum was essential for $R$. solanacearum virulence on tomato and Arabidopsis thaliana, (ii) HpaP was not secreted or translocated into plant cells, (iii) HpaP was fine tuning the secretion level of some type III substrates, and (iv) HpaP directly interacts with only one T3E (i.e., PopP1, renamed RipP1) (Lohou et al. 2014). These data prompted us to consider a more global approach to better characterize the role of HpaP by studying its role within both the bacterium and T3S. To address this characterization, we generated and analyzed the secretome of the $R$. solanacearum hpaP mutant using a mass spectrometry (MS)-based shotgun approach combined with a label-free quantification. Unexpectedly, the hpaP mutant secretome pattern was close to the wild-type pattern, except for six type III-associated substrates. Among them, we identified HrpJ, a putative component of the T3SS apparatus. We demonstrated that HrpJ is specifically secreted and translocated in planta by the hpaP mutant, and directed to the plasma membrane. We showed that HrpJ is essential for $R$. solanacearum T3S and virulence and is able to directly interact with HpaP. Using a local mapping population of 157 whole-genome sequenced natural accessions of $A$. thaliana, we observed genetic variation for local necrosis after infiltration of leaves with a disarmed Pseudomonas strain specifically delivering HrpJ. Genomewide association (GWA) mapping revealed a neat association peak with 12 top single-nucleotide polymorphisms (SNPs) centered on a plant acyl-transferase. Together, these findings strongly support the hypothesis that HpaP chaperones HrpJ, a predicted inner rod protein of $R$. solanacearum T3SS, preventing HrpJ in planta translocation. This specific interplay implicates a dual HpaP-HrpJ control of the bacterial virulence.

\section{RESULTS}

\section{hpaP mutation in $R$. solanacearum GMI1000 wild-type strain specifically alters the secretion of few type III-associated proteins.}

In order to identify how the HpaP T3S4 protein may monitor the secretion of $R$. solanacearum and, more specifically, its $\mathrm{T} 3 \mathrm{~S}$, we compared the secretomes of the hpaP mutant and of the GMI1000 wild-type strain. Both strains were grown for $8 \mathrm{~h}$ in a minimal medium, allowing induction of T3S. Secreted proteins were identified by liquid chromatography tandem MS (LC-MS/MS). A previous analysis of the wild-type secretome identified 228 proteins (Lonjon et al. 2016). In all, 174 proteins were identified in the hpaP mutant secretome (Supplementary Table S1). These proteins were classified into functional groups according to the $R$. solanacearum proteome database. We then performed a quantitative comparison of both secretomes and observed few differences between the two strains (Supplementary Fig. S1), with only 16 proteins significantly differentially secreted (Supplementary Table S2; Supplementary Fig. S2A). Interestingly, an analysis focused on type III secretomes clearly discriminates both strains (i.e., $58 \%$ of the overall variation explained by a strain effect) (Fig. 1A and B), with six proteins associated with the T3SS significantly differentially secreted (three of them showing the lowest $P$ values) (Supplementary Fig. S2B). More precisely, among the 41 type IIIassociated proteins detected, 4 were significantly less secreted 
by the hpaP mutant; namely, the RipF1_1 and RipF1_2 translocon proteins and the two T3Es RipW and RipAM. In contrast, two proteins were significantly more secreted by the $h p a P$ mutant; namely, the T3E RipAX2 and HrpJ, a protein of unknown function (Fig. 1C). These specific and differential secretion patterns were validated by immunoblotting (Supplementary Fig. S3).

\section{HrpJ is specifically translocated in planta}

by the hpaP mutant and is localized to plant cytoplasm.

HrpJ appeared specifically secreted in large amounts by the hpaP mutant (Fig. 1C; Supplementary Tables S1 and S2). To validate this observation, the kinetics of HrpJ secretion was studied by transforming both the wild-type strain and the $h p a P$ mutant with constructs of HrpJ-hemagglutinin (HA) fusion protein. HrpJ-HA was produced in an equivalent amount 8 and
$12 \mathrm{~h}$ after the induction of the secretion in the bacterial pellets of both strains and was no longer detected after $18 \mathrm{~h}$ (Fig. 2A). In the supernatants, a much stronger oversecretion of the HrpJ$\mathrm{HA}$ fusion protein was observed at 8 and $12 \mathrm{~h}$ after induction of the secretion in the hpaP mutant than in the wild-type strain (Fig. 2A). This atypical secretion pattern in the hpaP mutant prompted us to test whether the HrpJ protein is translocated in planta. To test this hypothesis, we first generated and transformed HrpJ-CyaA' fusion constructs in the GMI1000 wildtype strain, in the hpaP mutant, and in an hrcV-hpaP double mutant. We then performed translocation assays based on the adenylate cyclase reporter system. These three strains were infiltrated into Nicotiana tabacum leaves, which were harvested after $7 \mathrm{~h}$, and cyclic adenosine monophosphate (cAMP) levels were measured using the cAMP Biotrak competitive
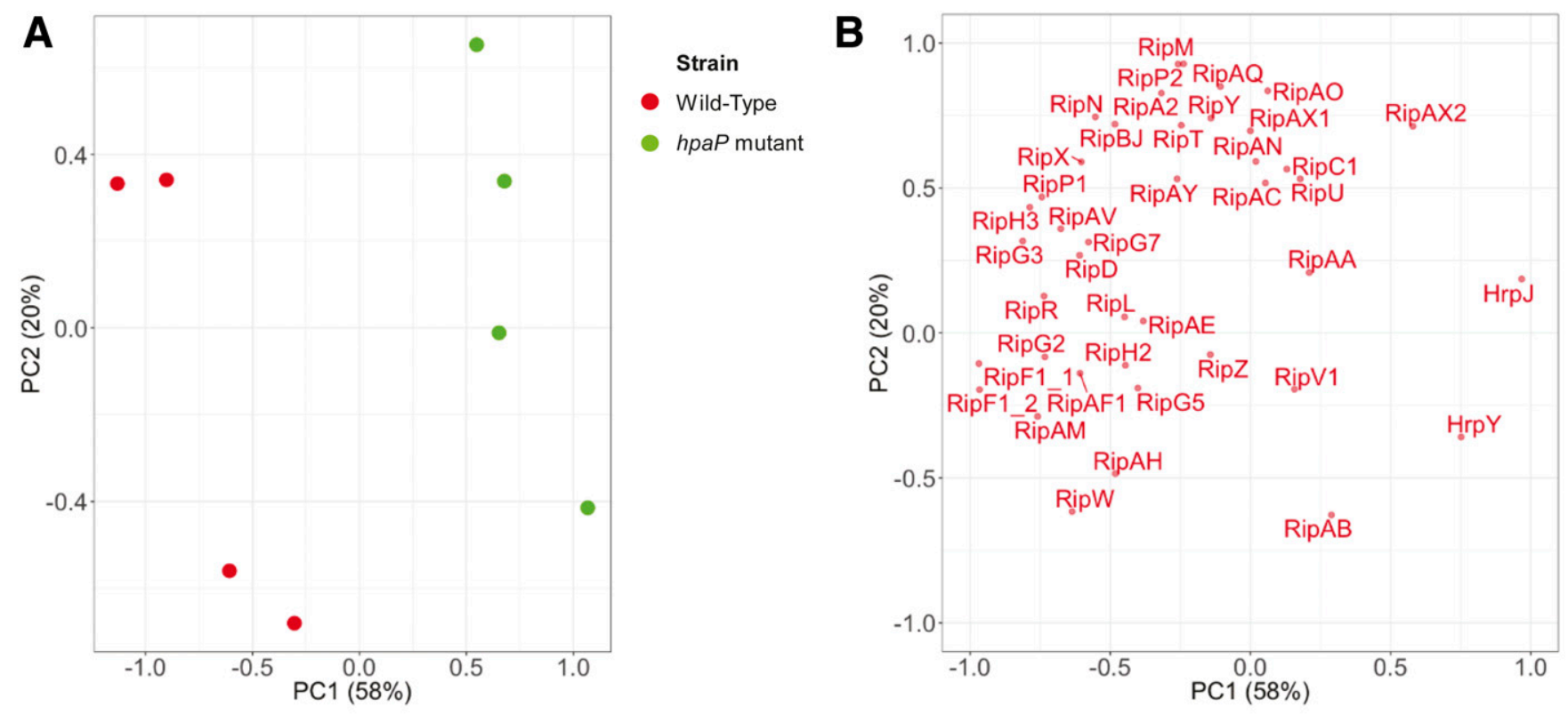

\section{C}

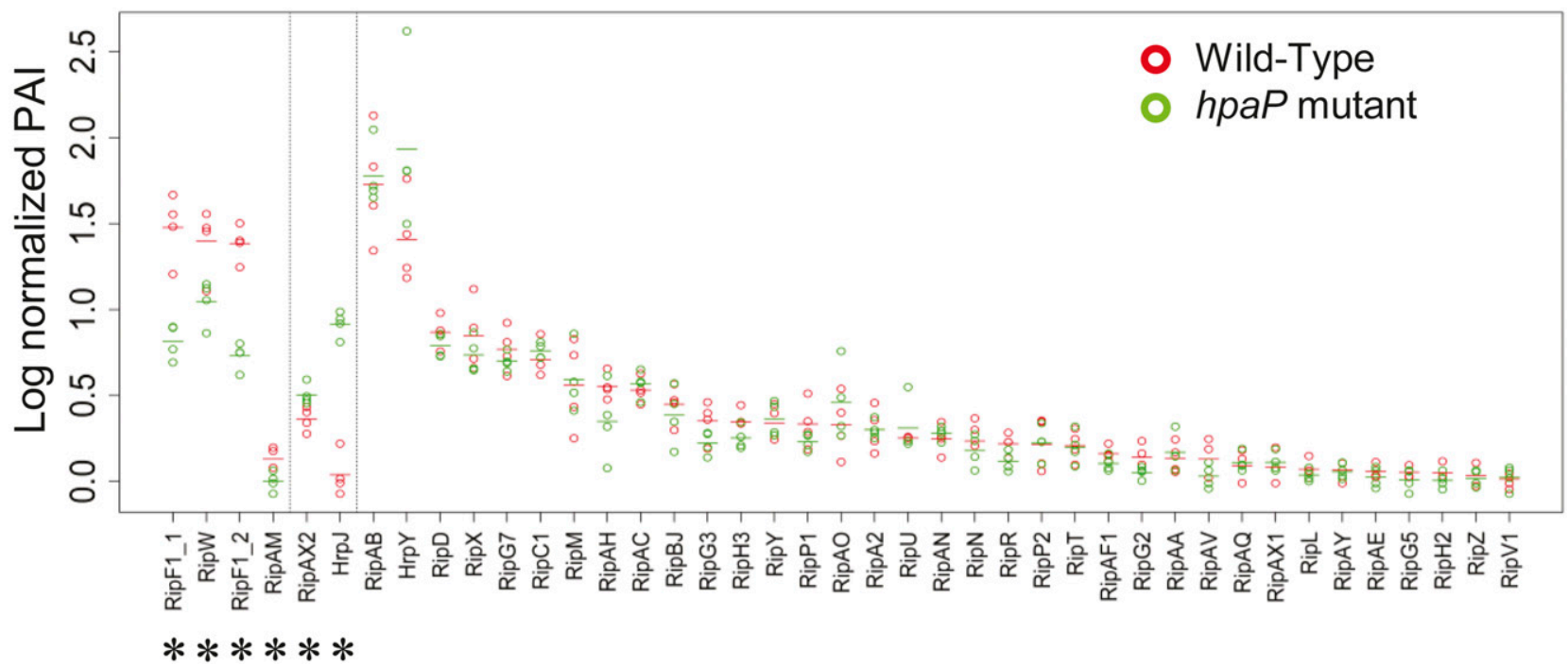

Fig. 1. Comparison of type III secretomes of the GMI1000 wild-type strain and of the hpaP mutant. A, Principal component analysis (PCA) with the detected type III-associated proteins in the wild-type strain and in the hpaP mutant highlights the strain effect on the first component, explaining 58\% of the total variance. B, Protein distribution on the same PCA. C, Log-normalized protein abundance index (PAI) values of type III-associated proteins detected in the wildtype (red) and in the hpaP mutant (green) secretomes. Four biological replicates were analyzed for each strain. Each dot represents a replicate; dashes represent the mean values of all four replicates. Asterisks highlight proteins presenting significantly different secretion levels between both strains (Student's $t$ test, $P$ value $<0.05$ ). The first panel encompasses proteins significantly secreted in a lower amount in the $h p a P$ mutant, the second panel proteins significantly secreted in a higher amount in the hpaP mutant, and third panel proteins nonsignificantly differentially secreted. 
enzyme immunoassay. High amounts of cAMP were detected when infiltrated with the hpaP mutant but not with the wildtype strain or the $h r c V$-hpaP double mutant (Fig. 2B). These data indicated that the HrpJ protein is specifically translocated into plant cells in the absence of the HpaP protein, and that this translocation is dependent on a functional T3SS.

We then looked for HrpJ localization in planta. We generated green fluorescent protein (GFP)-HrpJ and HrpJ-GFP fusion proteins and transiently expressed them in $N$. benthamiana by agroinfiltration. At $48 \mathrm{~h}$ after infiltration, confocal microscopy showed that the GFP-HrpJ fusion protein localized at the cytoplasm of $N$. benthamiana cells (Fig. 3A). A similar result was obtained for the HrpJ-GFP fusion protein when using $\mathrm{N}$ terminal GFP-tagged constructs (Fig. 3A). The GFP protein alone was analyzed as a control (Fig. 3A). In contrast to GFP protein, both HrpJ fusion proteins seem to be excluded from the plant cell nucleus. Production and stability of fusion proteins in the plant cells were controlled by immunoblotting (Fig. 3B).

\section{HpaP interacts with HrpJ.}

The specific secretion and translocation of HrpJ by the hpaP mutant suggested that HpaP protein may retain $\mathrm{HrpJ}$ secretion or translocation in the wild-type strain. Therefore, we tested whether HpaP could directly interact with HrpJ by performing glutathione $S$-transferase (GST) pull-down assays. GST and GST-HpaP fusion protein were immobilized on glutathione sepharose matrix, and incubated with 6-histidine (6His)-HrpJ. Eluates were analyzed using anti-GST- and anti-6His-specific antibodies. We were able to specifically detect 6His-HrpJ in the presence of GST-HpaP but not with GST alone (Fig. 4), indicating a direct interaction between HpaP and HrpJ. In a complementary step, we tested whether HpaP could also directly interact with the other proteins whose secretion level is modified in the hpaP mutant. We generated new GST-fusion

\section{A SECRETED PROTEINS}

\section{BACTERIAL PELLETS}
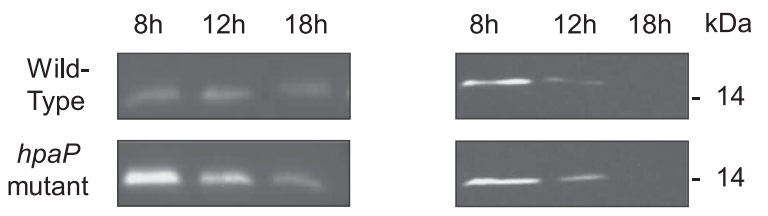

$\alpha \mathrm{HA}$

B

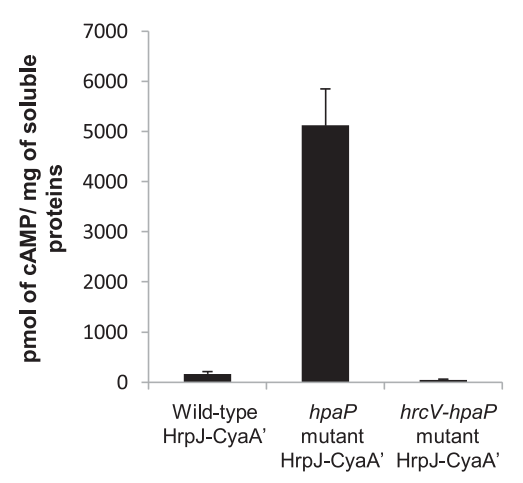

Fig. 2. Loss of function of HpaP leads to secretion and translocation of HrpJ. A, The GMI1000 wild-type strain and the hpaP mutant were transformed to express an HrpJ-hemagglutinin (HA) fusion protein. Secretion assays were performed and total proteins from the supernatants and pellets were detected by Western blot. B, Translocation assays of the HrpJ protein in Nicotiana tabacum leaves using an HrpJ-CyaA' fusion protein. Cyclic adenosine monophosphate (cAMP) levels were detected to determine the level of translocation of HrpJ-CyaA' protein in tobacco leaves for each strain. Error bars indicate the standard errors. Four independent biological replicates were made.
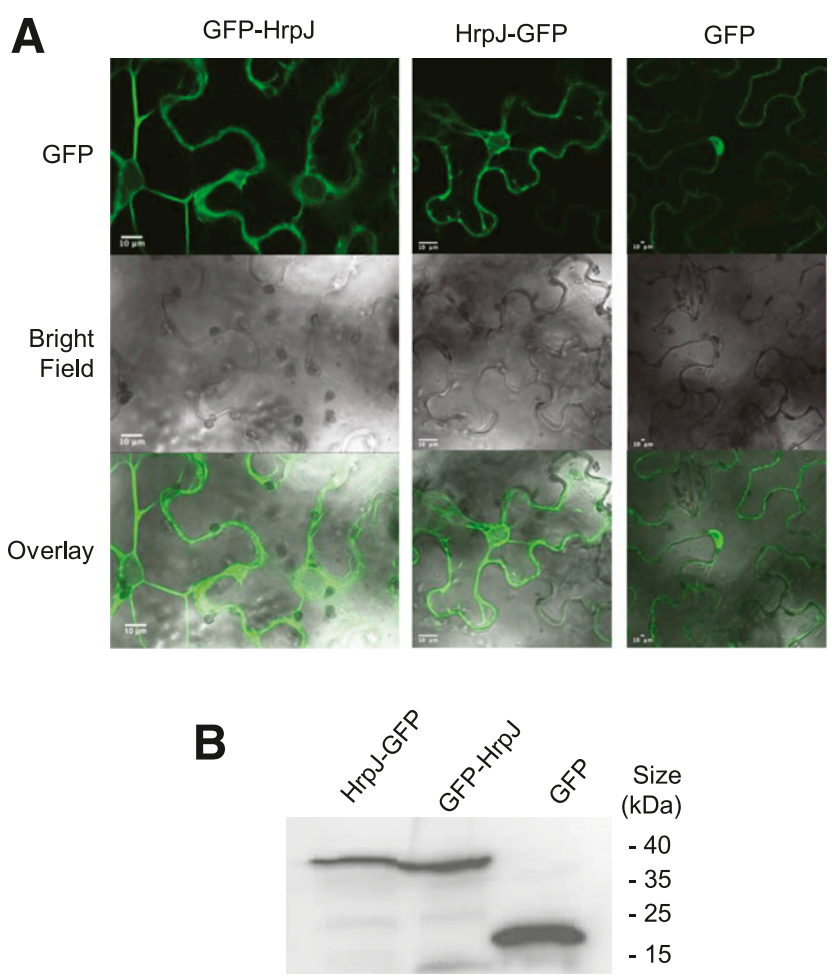

Fig. 3. HrpJ is localized in the cytoplasm of the plant cells. A, Live-cell imaging of the green fluorescent protein (GFP)-HrpJ and HrpJ-GFP fusion proteins and the GFP protein alone transiently expressed in Nicotiana benthamiana leaves by agroinfiltration. Live-cell imaging was performed with a laser-scanning confocal microscope 2 days after infiltration. GFP was excited at $488 \mathrm{~nm}$. GFP green fluorescence was collected at 500 to 550 $\mathrm{nm}$. Images displayed are the GFP signal, the bright field and overlays of GFP signal, and bright field. B, Western blotting on $N$. benthamiana leaves transiently expressing HrpJ-GFP, GFP-HrpJ, and GFP, 2 days after agroinfiltration, using specific anti-GFP antibody.

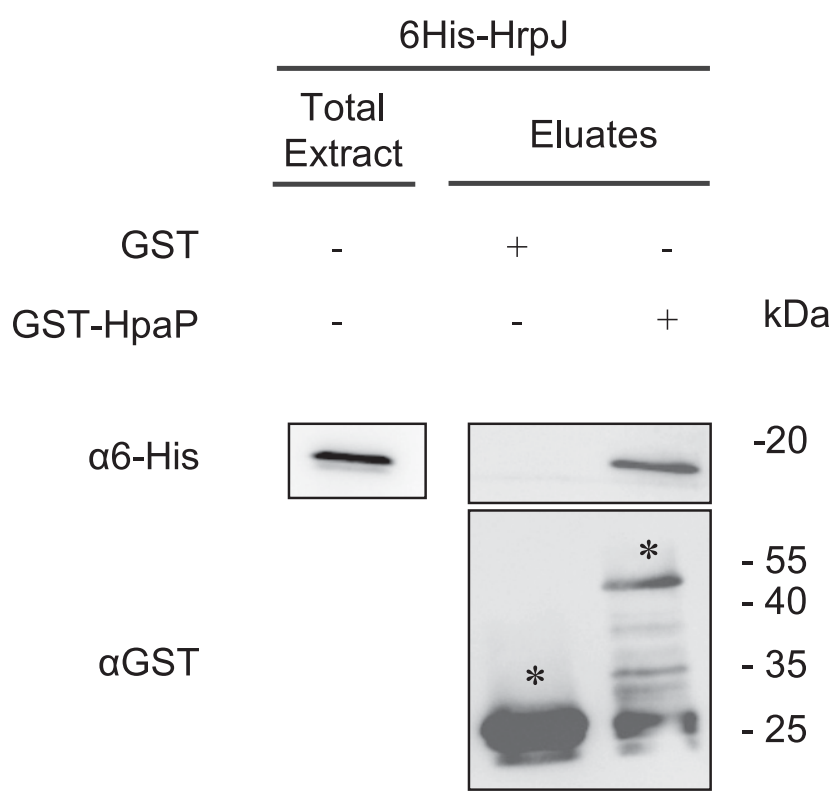

Fig. 4. HpaP physically interacts with HrpJ. Glutathione S-transferase (GST) and a GST-HpaP fusion protein were immobilized on glutathione sepharose and incubated with an Escherichia coli lysate containing 6-histidine (6His)-HrpJ. Total cell lysates and eluted proteins were analyzed by immunoblotting using antibodies directed against GST and the 6His epitope. Bands corresponding to GST and GST-HpaP fusion protein are marked with asterisks. Lower bands represent degradation products. Two biological replicates were performed with similar results. 
proteins and performed GST pull-down experiments with RipF1_1, RipF1_2, RipW, RipAX2, and RipAM. We added HrpJ in the assay as a positive control. With the exception of HrpJ, we were not able to identify a direct interaction between HpaP and all the fusion proteins tested (Supplementary Fig. S4).

\section{HrpJ is strictly required for $R$. solanacearum} pathogenicity, hypersensitive response elicitation, and T3S.

To go further into the functional characterization of HrpJ, we first evaluated the impact of the hrpJ mutation on $R$. solanacearum pathogenicity on $A$. thaliana plants. In the GMI1000 wild-type strain, $h r p J$ is the second gene of an operon containing eight genes. After generating an $h r p J$ nonpolar mutant and the corresponding complemented mutant (hrpJ::hrpJ+), A. thaliana plants were root inoculated with the GMI1000 wild-type strain, the hrpJ mutant, and the hrpJ::hrpJ+ complemented mutant. No disease was observed on $A$. thaliana inoculated with the $h r p J$ mutant, whereas an ectopic copy of the $h r p J$ gene induced disease (Fig. 5A and B). We then tested the ability of the hrpJ mutant to elicit the hypersensitive response (HR) on tobacco plants. All three strains were infiltrated into $N$. tabacum leaves at $10^{8} \mathrm{CFU} / \mathrm{ml}$. The $\mathrm{hrpJ}$ mutant did not elicit any HR, unlike the wild-type strain. The hrpJ::hrpJ+ complemented mutant restored a full HR (Fig. 5C).

To study the contribution of HrpJ to the secretion of T3Es, we performed secretion assay experiments with the four following strains: the GMI1000 wild-type strain, the T3SS defective $h r c V$ mutant, the hrpJ mutant, and the hrpJ::hrpJ+ complemented strain. Supernatants and cell pellets were harvested and analyzed by Western blot using specific anti-T3E antibodies. We monitored the secretion of five well-described T3Es: RipX, RipG7, RipAA, RipP1, and RipP2. The same amount of protein was detected in the cell pellets of the four strains studied for each T3E. As expected, no T3Es were detected in the hrcV mutant supernatant. Interestingly, we also did not detect any T3E secretion for the hrpJ mutant. This absence of secretion was restored to the wild-type level in the hrpJ::hrpJ+ complemented mutant (Fig. 5D). All together, these data indicate that $\mathrm{HrpJ}$ is required for $R$. solanacearum pathogenicity and HR elicitation on tobacco, and is an essential component for efficient type III secretion.

In planta delivery of HrpJ specifically triggers a necrosis on some Arabidopsis natural accessions, a phenotype associated with a plant acyl-transferase.

In order to follow the impact of HrpJ translocation in planta, we used a Pf0-1 engineered strain of the nonpathogenic $P$. fluorescens bacterium, carrying a heterologous T3SS apparatus (Thomas et al. 2009). We generated a Pf0-1-HrpJ strain to deliver directly into host cells an HrpJ-HA-tagged protein via the T3SS of $P$. fluorescens. Production and secretion of HrpJHA by $P$. fluorescens was validated in vitro by immunoblot (Fig. 6A). The Pf0-1 and Pf0-1-HrpJ strains were infiltrated in leaves of a French local mapping population of 180 natural accessions of $A$. thaliana, characterized by a very short linkage disequilibrium $\left(\boldsymbol{r}_{0.5}^{2}\right.$ of approximately $\left.18 \mathrm{bp}\right)$ that allows fine
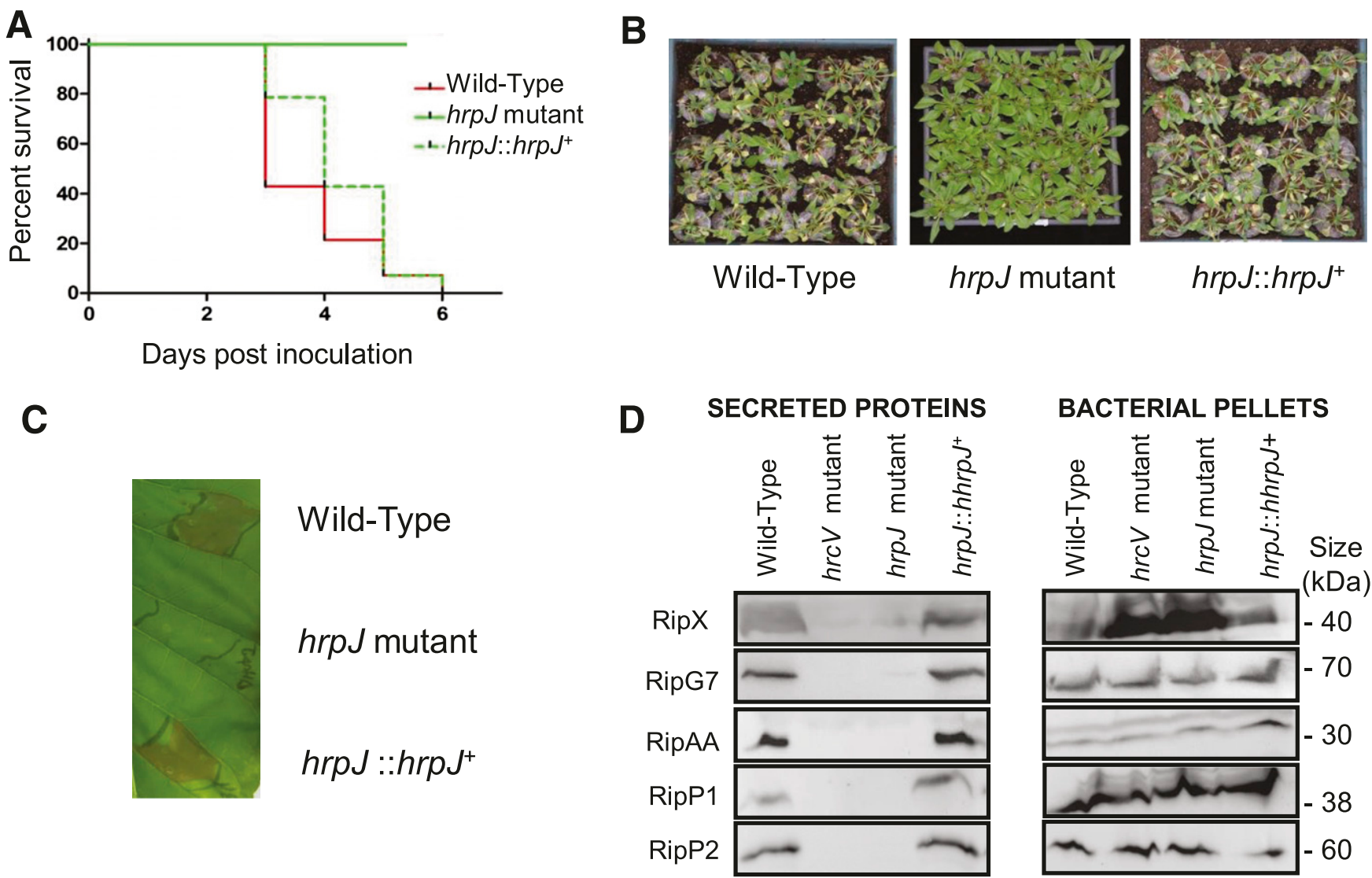

Fig. 5. HrpJ is required for pathogenicity, hypersensitive response (HR) elicitation, and effector secretion. A, Kaplan-Meier survival analysis of 16 inoculated Arabidopsis thaliana plants. The Gehan-Breslow-Wilcoxon test indicated that the GMI1000 wild-type strain curve (red) was significantly different from the hrpJ mutant curve (green) $(P$ value $<0.0001)$, contrary to the complemented hrpJ curve (dotted green) $(P$ value $=0.6189)$. B, Pictures of $A$. thaliana Col0 plants 5 days postinoculation. C, Wild-type strain, hrpJ mutant, and complemented hrpJ mutant were inoculated on Nicotiana tabacum leaves. HR was observed $24 \mathrm{~h}$ after leaf infiltration only with the wild-type and the complemented hrpJ mutant. D, Ralstonia solanacearum secretion assays were performed in type III-inducing conditions for the wild-type strain, $h r p J$ mutant, and complemented $h r p J$ mutant. Total proteins from supernatants and bacterial pellets were analyzed by Western blot using specific antibodies. For A, B, C, and D, two biological replicates were done with similar results. 
mapping of genomic regions associated with a natural variation of phenotypic traits down to the gene level (Brachi et al. 2013; Frachon et al. 2017; Huard-Chauveau et al. 2013). Symptoms of necrosis ranging from 0 to 3 were monitored 3 to 5 days after infiltration (Fig. 6B). To avoid nonspecific plant responses potentially caused by $P$. fluorescens, we eliminated 23 lines harboring symptoms after inoculation of the Pf0-1 strain. Among the remaining 157 accessions, we observed extensive genetic variation for the response to the Pf0-1-HrpJ strain, with the estimation of a highly significant broad-sense heritability values for each scoring day (day $3: H^{2}=0.56, P=5.2 \mathrm{e}-13$; day 4: $H^{2}=0.67, P<1 \mathrm{e}-16$; and day $\left.5: H^{2}=0.66, P<1 \mathrm{e}-16\right)$. Although no symptoms were observed for the majority of the lines, 16 lines exhibited a strong necrosis (Supplementary Table S3; Supplementary Fig. S5). The necrosis observed did not spread out of the infiltration zone. Thus, symptoms observed are most likely due to hypersensitive cell death rather than disease symptoms. However, because we do not have enough elements in terms of specificity of recognition, we preferred to be cautious by talking about necrosis instead of hypersensitive cell death. We then adopted a GWA mapping approach to finely map the genomic regions associated with natural variation of response to the Pf0-1HrpJ strain. We identified several peaks of association across the genome, including a major and neat peak of association located at the bottom of chromosome 3, 4 days after infiltration (Fig. 6C). This peak is composed of 12 top SNPs in a 2-kb region (between positions 18,639,008 and 18,640,870). Interestingly, those 12 SNPs are localized in the promoter, the $5^{\prime}$ untranslated region (UTR), and the coding region of a gene encoding for an HXXDacyl-transferase protein (At3g50290 gene) (Fig. 6D; Supplementary Table S4). This peak was also found 3 and 5 days after infiltration (Supplementary Figs. S6A and B).

At3g50290 protein does not directly interact with HrpJ.

To go further in the characterization of the At3g50290 HXXD-acyl-transferase, we analyzed the genomic sequence of At3g50290 in the local mapping population. We identified one accession (TOU-A6-62) containing all 12 top SNPs and displaying strong necrosis symptoms 5 days after infiltration (mean $=1.66)$. By comparison, the Col-0 accession of A. thaliana showed no symptoms. Among the 12 top SNPs, 7 were localized within the coding sequence of the At $3 g 50290$ gene, with 4 of the 7 leading to nonsynonymous mutation in the TOU-A6-62 accession. Four SNPs were localized in the promoter region of the At $3 g 50290$ gene and also in the coding region of the At3g50280 gene, which encodes another HXXDacyl-transferase of the same family as At3g50290. These four SNPs led to nonsynonymous mutations in the At3g50280 gene. Finally, one SNP was localized in the $5^{\prime}$ UTR region of the At3g50290 gene (Supplementary Table S5). In addition, the At3g50290 TOU-A6-62 allele harbored a TA insertion in position 808, absent in the Col-0 allele (Supplementary Fig. S7). We decided to clone the two allelic versions (TOU-A6-62 and Col0 alleles) of the At3g50290 gene to test whether the $R$. solanacearum HrpJ protein could interact with TOU-A6-62 or Col-0 At3g50290 proteins. First, yeast two-hybrid assays were performed using the LexA and Gal4 proteins fused with At3g50290 full-length protein from TOU-A6-62 and Col-0. In the case of an interaction between the LexA and Gal4 fusion proteins, yeasts are able to grow on a minimal medium lacking histidine. Yeasts were first transformed with the vectors encoding LexA-At3g50290 ${ }_{\mathrm{Col}-0}$, LexA-At3g50290 ${ }_{\text {TOU-A6-62 }}$, or Gal4-HrpJ and were mated to obtain diploids expressing both LexA and Gal4 fusion proteins. Diploids expressing Gal4-HrpJ/ LexA-At3g50290 ${ }_{\text {Col-0 }}$ or Gal4-HrpJ/LexA-At3g50290 fusion proteins did not grow on minimal medium lacking histidine, indicating that HrpJ did not directly interact with both alleles of At3g50290 tested in yeasts (Fig. 7A). Second, we performed GST pull-down experiments. We generated GSTAt3g50290 ${ }_{\text {Col-0 }}$ and GST-At3g50290 ${ }_{\text {TOU-A6-62 fusion proteins }}$ and looked for a putative interaction with 6 His-HrpJ fusion protein. 6 His-HrpJ was not eluted when incubated with the GST but is no more eluted with both GST fusion proteins (Fig. 7B). Hence, we could not identify any direct interaction between 6 His-HrpJ and At3g50290 two different techniques.

\section{DISCUSSION}

HpaP is a key regulator of early substrates of the T3SS.

$\mathrm{HpaP}$ and $\mathrm{HpaB}$ are two hrp-associated proteins that are highly conserved among strains in the $R$. solanacearum species
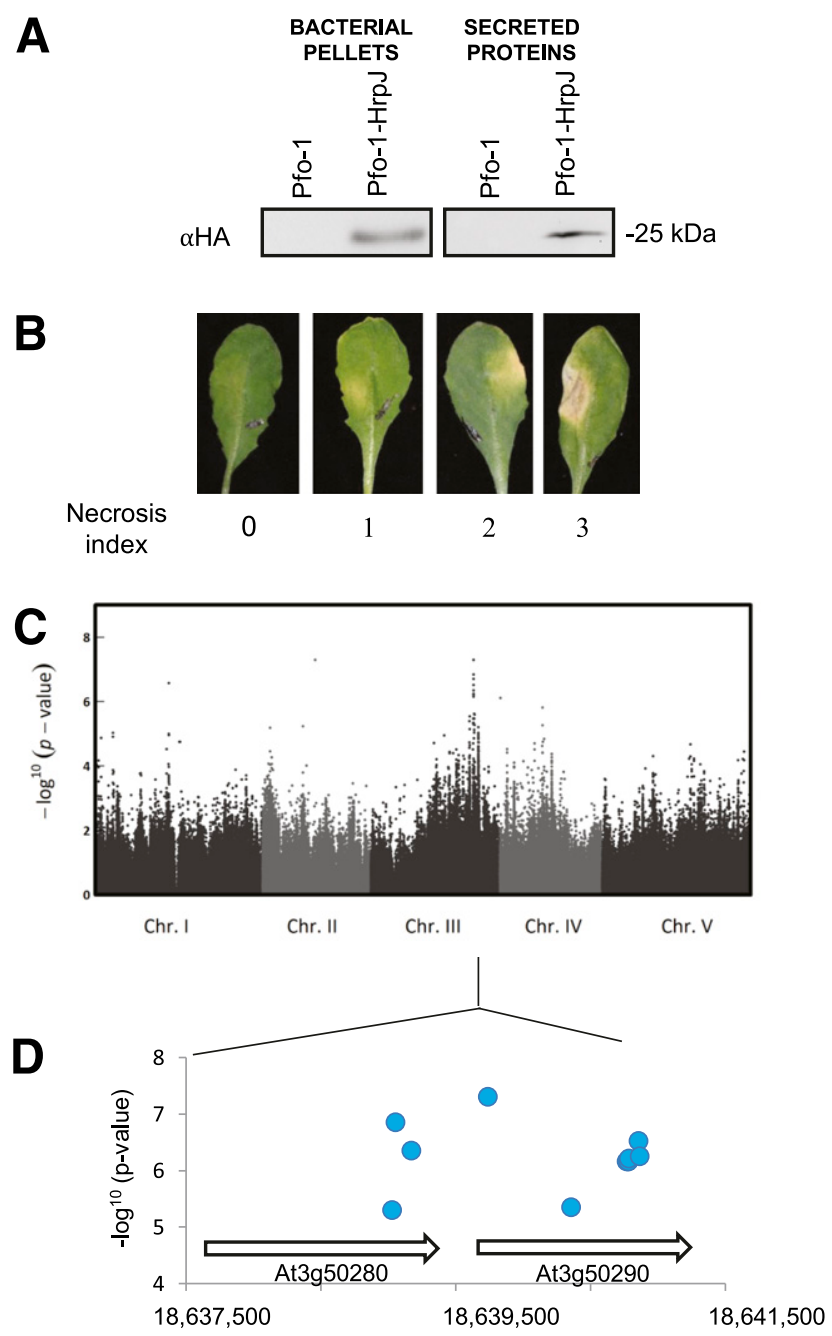

Fig. 6. Genome-wide association mapping identifies acyl-transferase genes as genetic determinants of HrpJ induced necrosis. A, HrpJ-hemagglutinin (HA) fusion protein was secreted by a nonpathogenic Pseudomonas fluorescens strain. After in vitro secretion assays in a type III induction condition for $P$. fluorescens, production and secretion of HrpJ-HA was validated after detection using anti-HA antibody in bacterial pellets and supernatants. B, Representative pictures of the notation scale used to phenotype Arabidopsis thaliana after inoculation with $P$. fluorescens delivering HrpJ. Half of the leaf has been infiltrated. C, Whole-genome scan of 981,617 single-nucleotide polymorphisms (SNPs) for association with necrosis 4 days after inoculation with $P$. fluorescens delivering HrpJ, across 157 accessions of a local population of $A$. thaliana. D, Gene models of a 4-kb genomic region surrounding the most significant associated SNPs. Blue dots represent the SNPs $\left(-\log ^{10}[P\right.$ value $\left.]>5\right)$, and numbers indicate positions in base pairs on chromosome 3 . 
complex and encoded by two genes located in the hrp gene cluster. In addition, they were demonstrated to be important for $R$. solanacearum virulence on Arabidopsis and tomato plants (Lohou et al. 2014; Lonjon et al. 2016, 2017). To finely characterize the involvement of $R$. solanacearum Hpa proteins in T3S, we previously set up and validated a powerful method to quantify and compare secretion levels between bacterial strains (Lonjon et al. 2016). Our previous work showed that HpaB was strongly affected in its T3S (Lonjon et al. 2016). In contrast, in this study, we observed few variations between the wild-type strain and the hpaP mutant secretomes, with 16 of 180 proteins modulated in their secretion. Among these 16 proteins, 10 were predicted to be secreted in a T3-independent way and only 6 T3 substrates exhibited up- and downregulations. Interestingly, four proteins $\mathrm{HpaP}$-dependent for their T3S (i.e., requiring HpaP for their full secretion)_RipF1_1, RipF1_2, RipW, and RipAM-were among the only seven proteins whose secretion was strictly $\mathrm{HpaB}$ independent (Lonjon et al. 2016). Thus, a clear and unexpected dichotomy of secretion pattern was observed for these four proteins. RipF1_1 and RipF1_2 are

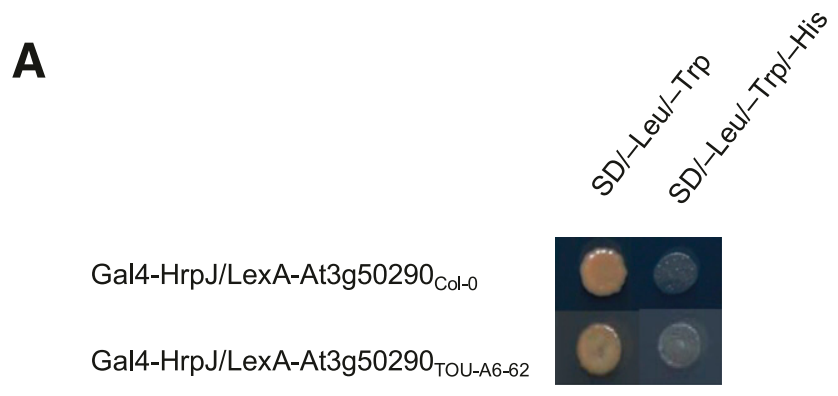

B

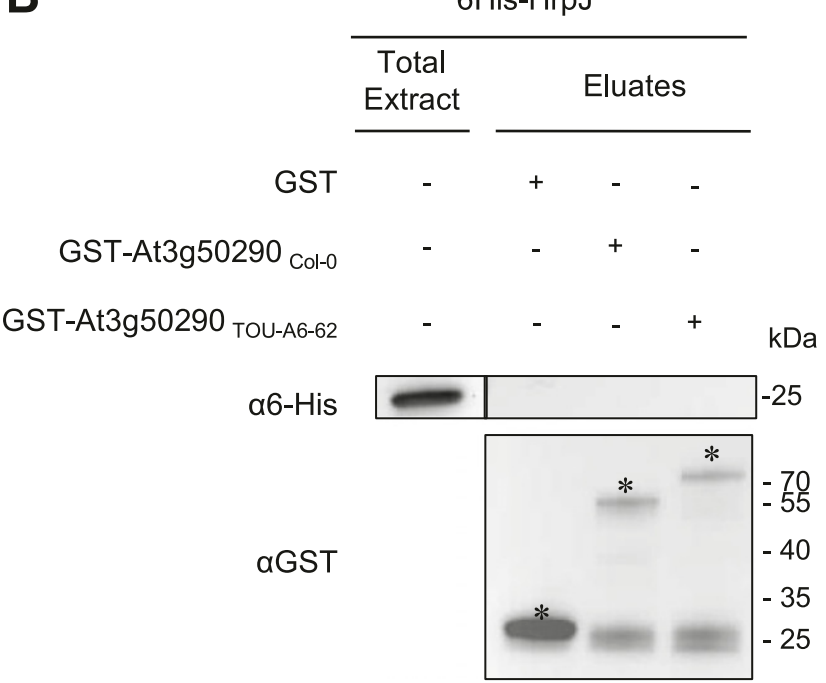

Fig. 7. HrpJ does not interact with At3g50290. A, Yeast cells were cotransformed with Gal4-HrpJ and LexA-At3g50290 (Col-0 allele) or LexA-At3g50290 (TOU-A6-62 allele). Double transformation and interaction were tested by plating yeasts on synthetic dropout medium lacking leucine and tryptophan (SD/-Leu/-Trp) and synthetic dropout medium lacking leucine, tryptophan, and histidine (SD/-Leu/-Trp/-His), respectively. B, Glutathione S-transferase (GST), GST-At3g50290 (Col-0 allele), and GST-At3g50290 (TOU-A6-62 allele) were immobilized on glutathione sepharose and incubated with an Escherichia coli lysate containing 6-histidine (6His)-HrpJ. Total cell lysates and eluted proteins were analyzed using antibodies directed against GST and the 6His epitope. Bands corresponding to GST and GST fusion proteins are marked with asterisks. Lower bands represent degradation products. For A and B, two biological replicates were performed with similar results. encoded by two duplicated genes and constitute GMI1000 translocon, and both are required for efficient effector translocation (Meyer et al. 2006; Peeters et al. 2013a). In our study, both appear strongly significantly reduced in their secretion in the hpaP mutant. In $X$. campestris pv. vesicatoria, the T3S4 protein $\mathrm{HpaC}$ also controls the secretion of the translocon protein XopA, through a direct interaction (Lorenz et al. 2008). In a different way, we did not detect an interaction between HpaP and RipF1_1 or RipF1_2, suggesting an indirect regulation in $R$. solanacearum. RipW and RipAM are two highly conserved T3Es belonging to the "core effectome" of the $R$. solanacearum species complex (Peeters et al. 2013a) and could be associated with the translocon proteins. Indeed, RipW belongs to the harpin family, harbors a pectate lyase domain (predicted to degrade pectate, a major component of the plant cell wall), and targets the plant cell wall (Li et al. 2010). Moreover, several studies showed that some harpins can dimerize and shape pores inside the plant membrane (Charkowski et al. 1998; Haapalainen et al. 2011). In another study, $P$. syringae pv. tomato harpins were also demonstrated to be involved in a multiprotein complex forming the bacterial translocon (Kvitko et al. 2007). In our previous work, we also classified RipAM as part of the early to intermediate T3S substrates (Lonjon et al. 2016). RipAM has the same secretion pattern as structural elements of T3SS (pilin and translocon proteins) and as $R$. solanacearum harpins (RipW and RipX), suggesting a role for RipAM in early events of the T3S. All of these data highlight a key role for HpaP in the early stages of T3S, reinforcing the hypothesis of a hierarchy of delivery of the T3 substrates in $R$. solanacearum through HpaP, where HpaP may be a positive regulator for the secretion of the translocon and associated proteins.

\section{HpaP controls the secretion of three effectors triggering immunity during the later stages of T3S.}

During the later stages of T3S, corresponding to T3E delivery, the roles of $\mathrm{HpaB}$ and $\mathrm{HpaP}$ seem to be inverted. $\mathrm{HpaB}$ controls the secretion of most of the T3Es, whereas HpaP modulates the secretion of few substrates. We identified HpaP as a negative regulator of the secretion of RipAX2, a T3E shown to trigger specific resistance to bacterial wilt in Solanum torvum (Nahar et al. 2014) and eggplant (Morel et al. 2018). In a previous study, we also showed that HpaP was a positive regulator of RipP1 and a negative regulator of RipAA T3S (Lohou et al. 2014). Both RipP1 and RipAA have been shown to trigger plant immune responses in Nicotiana or Petunia spp. (Lavie et al. 2002; Poueymiro et al. 2009). RipAX2, RipP1, and RipAA have been characterized as involved in effectortriggered immunity (Morel et al. 2018; Peeters et al. 2013b). We can hypothesize that their rapid recognition by the plant may limit the $R$. solanacearum invasion process, and a fine regulation of their secretion may benefit bacterial pathogenicity. To advance on these questions, it may be of particular interest to study T3S patterns in hpaP mutants of other wild-type strains.

\section{HpaP prevents HrpJ secretion, a structural component of the T3SS recognized by the plant.}

We demonstrated that HpaP and HrpJ proteins physically interact. The gene encoding HrpJ in $R$. solanacearum is localized in the hrp gene cluster, which contains regulatory and structural components of the T3SS. In X. campestris pv. vesicatoria, the homolog of $\mathrm{HrpJ}, \mathrm{HrpB} 2$, was described as a component of the inner rod of the T3SS, a periplasmic component that allows anchoring of the pilus of the T3SS in the bacterial outer membrane. A protein alignment of HrpJ with HrpB2 highlighted a conserved C-terminal domain between 
both proteins (Hartmann et al. 2012) (Supplementary Fig. S8). Therefore, HrpJ is a predicted internal membrane protein. However, we observed that, in the absence of HpaP, HrpJ was translocated in planta. Similar observations were made in other studies performed with $X$. campestris pv. vesicatoria where the proteins $\mathrm{HpaC}$ and HrpB2, homologs of HpaP and HrpJ, respectively, also physically interact, thereby leading to the inhibition of HrpB2 secretion by HpaC (Hartmann et al. 2012). Such a pattern has also been demonstrated in several animal bacterial pathogens, where the most prominent example concerns the YscP T3S4 protein of $Y$. enterocolitica, which inhibits the secretion of the YscI internal stem protein (Wood et al. 2008). However, to our knowledge, no data are available on the function of the YscI/HrpB2 family proteins in the host cell. Here, we observed the oversecretion or translocation of HrpJ protein in the hpaP mutant background. In a wild-type context, we cannot exclude the in planta translocation of HrpJ under specific conditions. To our knowledge, elements that regulate the stability of $h p a P$ messenger or of HpaP protein have not been reported in the literature yet. This is a challenging question that needs to be addressed if one wants to better understand the temporality of $h p a P$ regulation in planta which may, in turn, lead to mimicking hpaP mutant status. Therefore, it will be important to determine the translocated amount of HrpJ and the translocation timing of HrpJ in planta. Similarly, it would be of particular interest to evaluate the allocation of HrpJ protein within the T3SS apparatus and as a potential secreted effector into the plant cytoplasm.

In this study, we also showed that, once translocated in planta, the HrpJ protein was directed to the plant cytoplasm. In order to understand its function in planta, we searched for plant targets or for signaling pathways targeted by HrpJ through a GWA mapping approach. We identified an acyl-transferase protein with a predicted cytoplasmic localization, as observed for HrpJ. Interestingly, the At3g50290 allele from an accession leading to necrosis showed a TA insertion in the $5^{\prime}$ of the coding sequence (resulting in a protein 48 amino acids longer) in comparison with Col-0 sequence (where no necrosis was observed). This polymorphism could be responsible for a loss or gain of function linked to the necrosis observed. Our GWA mapping approach detected At3g50290 as the main candidate gene that genetically interacts with HrpJ. However, we were not able to detect a physical direct interaction between HrpJ and this acyl-transferase protein (from both alleles), despite the use of two different techniques. Thus, we do not know if this protein is a direct target of HrpJ, potentially requiring other partners in a protein complex, or if it is part of an indirect signaling cascade after HrpJ detection by the plant. This protein is part of the HxxxD-acyl-transferase family, comprising 55 members in A. thaliana (Zheng et al. 2009). This protein family has been poorly characterized to date. Indeed, only one member, the EPS1 protein, has been shown to be involved in defense mechanisms against $P$. syringae. EPS1 has been described as important for pathogenesis-related gene induction and for salicylic acid accumulation during pathogen infection (Zheng et al. 2009). Other members have been described as involved in lipid biosynthesis (Molina and Kosma 2015) or as essential compounds for setting up defense mechanisms (Raffaele et al. 2008, 2009). Lipid metabolism was also demonstrated to play an important role during plant-host interactions by modulating defense responses in plants and pathogen infection (Wenk 2006). This plant target is likewise relevant because acylation mechanisms are, like many posttranslational mechanisms, important elements in signaling cascades leading to HR-like responses or necrosis (Bhattacharjee et al. 2015; Withers and Dong 2017) and are also used by many T3Es to modify their targets in planta (Popa et al. 2016).
All these data allowed us to highlight the crucial role of HpaP in the control of T3S as a key switch protein that will (i) finely regulate the secretion of early or intermediate substrates of T3SS, (ii) potentially regulate the secretion of sensitive T3Es that may be recognized too early by the plant, and (iii) interact with and control a key element of the syringe, HrpJ, whose role is essential for a functional T3SS and for the virulence of the bacterium. In addition, using the natural genetic diversity of A. thaliana, we identified a plant acyl-transferase as a candidate gene associated with natural variation in response to HrpJ. To go further, it would be of particular interest to better characterize this candidate gene. Similar approaches were performed with the translocation of $P$. syringae HopAM1 T3E via $P$. fluorescens, allowing the identification of a quantitative trait locus involved in effector-triggered immunity linked to this effector (Iakovidis et al. 2016). Finally, future studies should benefit from the use of natural diversity on both plant and bacterium sides, notably challenging different accessions of A. thaliana to the hpaP mutant, to evaluate the versatility or robustness of the phenotypes observed.

\section{MATERIALS AND METHODS}

\section{Strains and media.}

Bacterial and yeast strains used in this work are listed in Supplementary Table S6. E. coli strains were grown at $37^{\circ} \mathrm{C}$ in Luria-Bertani medium (Bertani 1951). Agrobacterium tumefaciens strains were grown at $28^{\circ} \mathrm{C}$ in Luria-Bertani medium. $R$. solanacearum strains were grown in complete media as previously described (Plener et al. 2010). P. fluorescens strains were grown in complete King's B medium or in minimal medium $\left(50 \mathrm{mM} \mathrm{KPO}{ }_{4}, \mathrm{pH} 5.7 ; 7.6 \mathrm{mM}\left(\mathrm{NH}_{4}\right)_{2} \mathrm{SO}_{4} ; 1.7 \mathrm{mM}\right.$ $\mathrm{MgCl}_{2} ; 1.7 \mathrm{mM} \mathrm{NaCl} ; 10 \mathrm{mM}$ fructose; and $10 \mathrm{mM}$ mannitol) (Heidrich et al. 2011). When needed, antibiotics were added at the following final concentrations: kanamycin at $50 \mathrm{mg} / \mathrm{liter}$, spectinomycin at $40 \mathrm{mg} / \mathrm{liter}$, gentamycin at $10 \mathrm{mg} / \mathrm{liter}$, and tetracycline at $10 \mathrm{mg} /$ liter for $R$. solanacearum; kanamycin at $25 \mathrm{mg} / \mathrm{liter}$, gentamycin at $10 \mathrm{mg} / \mathrm{liter}$, tetracycline at $10 \mathrm{mg} / \mathrm{liter}$, ampicillin at $50 \mathrm{mg} / \mathrm{liter}$, and chloramphenicol at $25 \mathrm{mg} / \mathrm{liter}$ for E. coli; chloramphenicol at $25 \mathrm{mg} / \mathrm{liter}$, tetracycline at $10 \mathrm{mg} / \mathrm{liter}$, and gentamycin at $15 \mathrm{mg} / \mathrm{liter}$ for $P$. fluorescens; and rifampicin at $50 \mathrm{mg} / \mathrm{liter}$, kanamycin at $50 \mathrm{mg} / \mathrm{liter}$, and gentamycin at $10 \mathrm{mg} / \mathrm{liter}$ for A. tumefaciens. Yeast strains were grown in complete yeast-peptone-glucoseadenine (YPGA) medium (yeast extract at $10 \mathrm{~g} /$ liter, bactopeptone at $20 \mathrm{~g} / \mathrm{liter}$, glucose at $20 \mathrm{~g} / \mathrm{liter}$, and adenine at $30 \mathrm{mg} /$ liter) or in SD minimal media (yeast nitrogen base without amino acids at $6.7 \mathrm{~g} /$ liter and minimal SD base at 0.62 g/liter [Takara Bio. Inc, Kusatsu, Japan], and glucose at 20 $\mathrm{g} /$ liter; $\mathrm{pH}$ 5.8). When needed, amino acids were added at the following concentrations: histidine at $20 \mathrm{mg} / \mathrm{liter}$, leucine at $100 \mathrm{mg} /$ liter, and tryptophane at $20 \mathrm{mg} / \mathrm{liter}$.

\section{Vectors and cloning.}

Vectors used in this study are listed in Supplementary Table S6. The plasmids in pENTR SD/D TOPO were generated following the manufacturer's instructions (Thermo Fisher Scientific, Waltham, MA, U.S.A.) using specific primers listed in Supplementary Table S7. Genes cloned in the pDONR207 plasmid were amplified in two steps. The first PCR was performed using the specific primers indicated in Supplementary Table S7. The second PCR was performed using $1 \mu$ of the first PCR as a matrix and oNP291-oNP292 universal primers. PCR products were cloned into pDONR207 using the Gateway BP reaction following the manufacturer's conditions (Thermo Fisher Scientific). Final plasmids were generated using the Gateway LR reaction. 


\section{Generation of $R$. solanacearum hrpJ mutant.}

The $h r p J$ mutant was generated using the $s a c B$-based system for marker-free gene deletion, as previously described (Perrier et al. 2018). To generate the hrpJ::hrpJ+ complemented mutant, a 1.5-kb region encompassing $h r p J$ and its native promoter was amplified $(1,092,572$ to $1,094,073$ region in the megaplasmid of $R$. solanacearum) with oFL179 and oFL180 primers and ligated into the pNP329 plasmid into KpnI, XbaI restriction sites to generate pFL147. pFL147 was then linearized using $S c a \mathrm{I}$ restriction enzyme and transformed into the hrpJ mutant for stable insertion in a large noncoding chromosomic region downstream of the $\operatorname{glm} S$ gene. Primers used in this study are listed in Supplementary Table S7.

\section{Generation of $\boldsymbol{P}$. fluorescens Pf0-1-HrpJ strain.}

The HrpJ sequence was introduced by LR recombination in pBBR1-AvrRps4prom-GWY-3HA destination vector that allows the expression, under the control of the AvrRps4 promoter sequence (504 bp of promoter sequence PCR amplified from avrRps4Pip151 genomic clone), of proteins tagged in the Cterminus end with the 3-HA epitope tag (Thomas et al. 2009) (Supplementary Table S6). Final expression vectors were transformed in strain Pf0-1 using triparental mating (Ditta et al. 1980).

\section{Secretion or translocation assays and immunoblot analysis.}

For $R$. solanacearum, in vitro secretion assays were performed as previously described (Lonjon et al. 2018). For each experiment, two independent assays were carried out. Translocation assays were performed as previously described on N. tabacum (Cunnac et al. 2004; Lonjon et al. 2018). The cAMP production was measured using the cAMP Biotrak enzyme immunoassay system kit by GE Healthcare (Buckinghamshire, U.K.). Four independent biological replicates were performed.

For $P$. fluorescens secretion experiments, strains were grown overnight on King's B medium (King et al. 1954) with $\mathrm{MgSO}_{4}$ $(5 \mathrm{mM})$ agar plates containing appropriate antibiotics at $28^{\circ} \mathrm{C}$ (Supplementary Table S6). Cells were inoculated in King's B with $\mathrm{MgSO}_{4}(5 \mathrm{mM})$ liquid medium containing antibiotics and shaken overnight at $28^{\circ} \mathrm{C}$. Cells were then collected by centrifugation at 3,000 $\times g$ during $10 \mathrm{~min}$ and washed with minimal media. Cells were diluted to a final optical density (OD) of 0.2 in minimal media lacking antibiotics and put in a rotary shaker for $14 \mathrm{~h}$ at $21^{\circ} \mathrm{C}$. Supernatants and bacterial cells were separated by centrifugation at $3,000 \times g$ for $10 \mathrm{~min}$. Bacterial cells were resuspended with $450 \mu \mathrm{l}$ of water, and $150 \mu \mathrm{l}$ of $2 \times$ Laemmli buffer was added. Supernatants were filtered through $0.22-\mu \mathrm{m}$ sterile filters. Proteins from the supernatants were precipitated with trichloroacetic acid and resuspended in $2 \times$ Laemmli buffer. Pellets and supernatant fractions were loaded onto sodium dodecyl sulfate polyacrylamide gel electrophoresis (SDS-PAGE) gels for immunoblot analysis. Antibodies used for Western blotting were RipG7, RipP1, RipP2, RipX, RipAA, and an anti-HA coupled with horseradish peroxidase (Santa Cruz Biotechnology, Santa Cruz, CA, U.S.A.). Two biologically independent experiments were performed.

\section{Secretome sample preparation and MS analysis.}

For secretome sample preparation, hpaP mutant concentrated supernatants were migrated onto an SDS-PAGE 10\% bisacrylamid gel and portions of gels that contained the proteins ( $1 \mathrm{~cm}$ of sample migration) were cut for shotgun MS analyses. A Q Exactive mass spectrometer (Thermo Fisher Scientific, San Jose, CA, U.S.A.) coupled to Eksigent 2Dnano LC (AB-Sciex, Framingham, MA, U.S.A.) were used for the nano-LCMS/MS analysis. All of the experimental procedures, data processing, and bioinformatics analysis were performed as described by Lonjon et al. (2016). The $R$. solanacearum strain GMI1000 database was downloaded from the $R$. solanacearum database site $(5,122$ protein entries). For protein quantification and normalization, identified proteins were filtered and grouped using X!TandemPipeline, as previously described by Lonjon et al. (2016). Label-free quantification was achieved in two steps. First, the spectral counting (SC) determined the relative quantification of proteins from their number of spectra obtained with tryptic peptides in MS. Second, we calculated the protein abundance index (PAI) for every protein, dividing SC data of the observed protein by the number of theoretically observable tryptic peptides for that protein. PAI values were then normalized by the sum of the PAIs on each sample. Normalized PAI values were then $\log _{2}$ transformed. The $\log _{2}$-transformed data were scaled repeat-wise in order to avoid any bias due to the existence of four independent biological repeats. Student's $t$ tests were subsequently run in order to discriminate proteins differentially quantified between the wild-type strain and the hpaP mutant. All statistical procedures were carried out under the $\mathrm{R}$ v3.5.3 environment using base packages as well as "mixOmics" (v6.6.2) (Rohart et al. 2017), "tidyverse" (v1.2.1) (Wickham, 2017), and "ggrepel" (Slowikowski, 2019). The R source code created for this study is available upon request.

\section{Agrobacterium-mediated expression of proteins}

in plant cells and confocal analysis.

A. tumefaciens strain GV3101 carrying GFP-derived plasmids was resuspended in infiltration medium $\left(10 \mathrm{mM} \mathrm{MgCl}_{2}\right.$, $10 \mathrm{mM}$ morpholine ethanesulfonic acid, and $150 \mu \mathrm{M}$ acetosyringone) to a final OD of 0.6 , and incubated for $2 \mathrm{~h}$ at room temperature. Resuspended cells were infiltrated into leaves of 4-week-old $N$. benthamiana plants with a 1-ml needleless syringe. The infiltrated plants were incubated in growth chambers for a 16-h day length at $20^{\circ} \mathrm{C}$. At $48 \mathrm{~h}$ after infiltration, leaf disks taken in infiltrated areas were ground with a mixer mill (MM400; Retsch, Haan, Germany) and homogenized in $2 x$ Laemmli buffer in order to be analyzed by Western blotting to control the gene expression levels.

\section{GST pull-down assays.}

GST and 6His fusion proteins were synthesized in E. coli BL21(DE3). Bacterial cells from $50 \mathrm{ml}$ of cultures were resuspended in phosphate buffer salt (PBS) and lysated with a French press. Cellular debris were eliminated by centrifugation. GST and GST fusion proteins were immobilized on a glutathione sepharose matrix, preliminarily washed with PBS, for $30 \mathrm{~min}$. Unbound proteins were washed with PBS, and the glutathione sepharose matrix was incubated with $500 \mu \mathrm{l}$ of E. coli cell lysates containing the $6 \mathrm{His}$ fusion proteins for $2 \mathrm{~h}$. Unbound proteins were washed with PBS. Proteins were eluted with $10 \mathrm{mM}$ reduced glutathione. Eluted proteins and protein lysates were analyzed by SDS-PAGE and immunoblotting using antibodies specific for the 6His epitope and the GST (Roche Applied Science, Mannheim, Germany). Experiments were repeated at least twice.

\section{Yeast two-hybrid assays.}

The two yeast strains used in this study were Y187 (MAT $)$ and L40 (MATa) (Supplementary Table S6). Y187 and L40 strains were transformed with pNP377 derivative plasmids (Gal4 fusion proteins) and pNP378 derivative plasmids (LexA fusion proteins), respectively, using the LiAc method (Gietz 2014). For matting between Y187 and L40 strains, one fresh colony of each transformed yeast strain was resuspended in $500 \mu \mathrm{l}$ of YPGA liquid media. Then, $60 \mu \mathrm{l}$ of YPGA liquid 
media was mixed with $20 \mu$ of cell suspension of each yeast strain and incubated overnight at $28^{\circ} \mathrm{C}$ on a rotary shaker (200 rpm). Next, $3 \mu \mathrm{l}$ was plated on minimal medium lacking leucine and tryptophane to check the efficiency of the mating and on minimal medium lacking leucine, tryptophane, and histidine to test the interaction between the two fusion proteins.

\section{Plant inoculation assays.}

For $R$. solanacearum inoculation on Arabidopsis thaliana and tobacco plants, inoculations were performed as previously described at $10^{8} \mathrm{CFU} / \mathrm{ml}$ (Deslandes et al. 2003; Lonjon et al. 2016; Poueymiro et al. 2009). For A. thaliana, disease development was monitored every day, and plants with at least $50 \%$ wilting were considered to be dead for the statistical survival analysis. To compare the disease development of two given strains, we used the Kaplan-Meier survival analysis with the Gehan-BreslowWilcoxon test (Bland and Altman 1998). A $P$ value $<0.05$ was considered significant, indicating that the Ho hypothesis of similarity of the survival experience of the tested strain can be rejected. Statistical analyses were done with Prism (version 5.00; GraphPad Software, La Jolla, CA, U.S.A.). For tobacco, HR appearance was monitored 24 and $48 \mathrm{~h}$ after infiltration.

For $P$. fluorescens inoculations, we used 192 whole-genome sequenced natural accessions from the highly polymorphic local population TOU-A (Burgundy, France) (Frachon et al. 2017) (Supplementary Table S3). Two experiments of 576 and 1,344 plants were set up according to a randomized complete block design) of three and seven experimental blocks for the infiltration with Pf0-1 and Pf0-1-HrpJ strains, respectively. Each block corresponded to one plant per accession. Seeds were directly sown in Jiffy pots (Jiffy France, Lyon, France) and plants were grown for 5 weeks in short-day conditions at $22^{\circ} \mathrm{C}$ and $70 \%$ humidity with $9 \mathrm{~h}$ of light $\left(250 \mu \mathrm{mol} \mathrm{m} \mathrm{m}^{-2} \mathrm{~s}^{-1}\right)$. No germination was observed for 12 accessions, which were therefore discarded from the study. The remaining 180 accessions were infiltrated with a syringe without needle with either Pf0-1 or Pf0-1-HrpJ strains, and incubated in the same conditions. Three leaves were infiltrated per plant. Inocula were adjusted to an OD at $600 \mathrm{~nm}$ of 0.2 in $10 \mathrm{mM} \mathrm{MgCl}_{2}$. For phenotyping, the infiltrated leaves were scored for necrosis response from 3 to 5 days postinoculation, following a scale ranging from 0 to 3 (Fig. 6B). For each plant, we estimated a necrosis index by averaging the values obtained for the three leaves.

To explore the natural genetic variation of the necrosis index among the 180 accessions infiltrated with the Pf0-1-HrpJ strain, we first eliminated 23 lines harboring symptoms after inoculation of the Pf0-1 strain, thereby allowing us to avoid nonspecific plant responses potentially caused by $P$. fluorescens. Based on the necrosis data obtained for the remaining $157 \mathrm{ac}-$ cessions, we then used the following mixed model (MIXED procedure in SAS 9.3; SAS Institute Inc., Cary, NC, U.S.A.):

$$
\text { necrosis index }_{\mathrm{ij}}=\mu+\text { block }_{\mathrm{i}}+\text { accession }_{\mathrm{j}}+\varepsilon_{\mathrm{ij}}
$$

where $\mu$ is the overall mean of the phenotypic data, "block" accounts for differences in microenvironmental conditions between the seven experimental blocks, "accession" corresponds to the genetic differences among the 157 natural accessions, and $\varepsilon$ is the residual term. The factor "accession" was treated as a random effect. This random term was tested with likelihood ratio tests of models with and without this effect. Based on model 1, best linear unbiased predictors (BLUPs) were obtained for each accession for each scoring day. Because A. thaliana is a highly selfing species (Platt et al. 2010), BLUPs correspond to genotypic values of accessions.

Based on variance components estimated by REML (PROC VARCOMP procedure in SAS 9.3; SAS Institute Inc.), the broad-sense heritability of the necrosis index $\left(H^{2}\right)$ was estimated for each scoring day as $H^{2}=\mathrm{V}_{\mathrm{F}} /\left[\mathrm{V}_{\mathrm{F}}+\left(\mathrm{V}_{\mathrm{R}} / n\right)\right]$, where $\mathrm{V}_{\mathrm{F}}$ is the estimated between-accession variance component, $V_{R}$ is the residual variance, and $n$ is the number of replicates per accession (i.e., $n=7$ ).

\section{GWA mapping.}

To fine map genomic regions associated with natural variation of necrosis index among the 157 accessions infiltrated with the Pf0-1-HrpJ strain, we run a mixed-model approach implemented in the software Efficient Mixed-Model Association Expedited (EMMAX) (Kang et al. 2010). In this model, the effect of the demographic history of the TOU-A population was controlled by including a genetic kinship matrix as a covariate. This kinship matrix was estimated on the whole set of 1,902,592 SNPs detected among the 157 accessions (Frachon et al. 2017). Because rare alleles may lead to an inflation of low $P$ values (Atwell et al. 2010; Brachi et al. 2010; Kang et al. 2010), we only considered SNPs with a minor allele relative frequency $>7 \%$, leaving us with 989,221 SNPs.

\section{ACKNOWLEDGMENTS}

We thank L. Deslandes for the gift of the RipP2 antibody (also known as PopP2), N. Peeters for providing pNP377 and pNP378 plasmids, and D. Latrèche for technical assistance for immunoblotting with T3Es and secretion assays. Proteomics analyses were performed on the PAPPSO platform, which is supported by INRA, the Ile-de-France regional council, IBiSA, and CNRS.

\section{AUTHOR-RECOMMENDED INTERNET RESOURCES}

CNRS website: http://www.cnrs.fr

IBiSA website: https://www.ibisa.net

Ile-de-France regional council website:

https://www.iledefrance.fr/education-recherche

INRA website: http://www.inra.fr

PAPPSO platform: http://pappso.inra.fr

$R$. solanacearum proteome database: https://iant.toulouse.inra.fr/bacteria/ annotation/cgi/ralso.cgi

$\mathrm{X}$ !TandemPipeline: http://pappso.inra.fr/bioinfo/xtandempipeline/

\section{LITERATURE CITED}

Agrain, C., Callebaut, I., Journet, L., Sorg, I., Paroz, C., Mota, L. J., and Cornelis, G. R. 2005. Characterization of a type III secretion substrate specificity switch (T3S4) domain in YscP from Yersinia enterocolitica. Mol. Microbiol. 56:54-67.

Atwell, S., Huang, Y. S., Vilhjálmsson, B. J., Willems, G., Horton, M., Li, Y., Meng, D., Platt, A., Tarone, A. M., Hu, T. T., Jiang, R., Muliyati, N. W., Zhang, X., Amer, M. A., Baxter, I., Brachi, B., Chory, J., Dean, C., Debieu, M., de Meaux, J., Ecker, J. R., Faure, N., Kniskern, J. M., Jones, J. D. G., Michael, T., Nemri, A., Roux, F., Salt, D. E., Tang, C., Todesco, M., Traw, M. B., Weigel, D., Marjoram, P., Borevitz, J. O., Bergelson, J., and Nordborg, M. 2010. Genome-wide association study of 107 phenotypes in Arabidopsis thaliana inbred lines. Nature 465:627-631.

Bertani, G. 1951. Studies on lysogenesis. I. The mode of phage liberation by lysogenic Escherichia coli. J. Bacteriol. 62:293-300.

Bhattacharjee, S., Noor, J. J., Gohain, B., Gulabani, H., Dnyaneshwar, I. K., and Singla, A. 2015. Post-translational modifications in regulation of pathogen surveillance and signaling in plants: The inside- (and perturbations from) outside story. IUBMB Life 67:524-532.

Bland, J. M., and Altman, D. G. 1998. Survival probabilities (the KaplanMeier method). BMJ 317:1572-1580.

Brachi, B., Faure, N., Bergelson, J., Cuguen, J., and Roux, F. 2013. Genome-wide association mapping of flowering time in Arabidopsis thaliana in nature: Genetics for underlying components and reaction norms across two successive years. Acta Bot. Gallica 160:205-219.

Brachi, B., Faure, N., Horton, M., Flahauw, E., Vazquez, A., Nordborg, M., Bergelson, J., Cuguen, J., and Roux, F. 2010. Linkage and association mapping of Arabidopsis thaliana flowering time in nature. PLoS Genet. 6:e1000940. 
Büttner, D. 2012. Protein export according to schedule: Architecture, assembly, and regulation of type III secretion systems from plant- and animal-pathogenic bacteria. Microbiol. Mol. Biol. Rev. 76:262-310.

Büttner, D. 2016. Behind the lines-Actions of bacterial type III effector proteins in plant cells. FEMS Microbiol. Rev. 40:894-937.

Büttner, D., and He, S. Y. 2009. Type III protein secretion in plant pathogenic bacteria. Plant Physiol. 150:1656-1664.

Büttner, D., Lorenz, C., Weber, E., and Bonas, U. 2006. Targeting of two effector protein classes to the type III secretion system by a HpaC- and HpaB-dependent protein complex from Xanthomonas campestris pv. vesicatoria. Mol. Microbiol. 59:513-527.

Charkowski, A. O., Alfano, J. R., Preston, G., Yuan, J., He, S. Y., and Collmer, A. 1998. The Pseudomonas syringae pv. tomato HrpW protein has domains similar to harpins and pectate lyases and can elicit the plant hypersensitive response and bind to pectate. J. Bacteriol. 180:5211-5217.

Cornelis, G. R., Boland, A., Boyd, A. P., Geuijen, C., Iriarte, M., Neyt, C., Sory, M.-P., and Stainier, I. 1998. The virulence plasmid of Yersinia, an antihost genome. Microbiol. Mol. Biol. Rev. 62:1315-1352.

Costa, T. R. D., Felisberto-Rodrigues, C., Meir, A., Prevost, M. S., Redzej, A., Trokter, M., and Waksman, G. 2015. Secretion systems in Gramnegative bacteria: Structural and mechanistic insights. Nat. Rev. Microbiol. 13:343-359.

Cunnac, S., Occhialini, A., Barberis, P., Boucher, C., and Genin, S. 2004. Inventory and functional analysis of the large Hrp regulon in Ralstonia solanacearum: Identification of novel effector proteins translocated to plant host cells through the type III secretion system. Mol. Microbiol. 53: 115-128.

Deng, W., Marshall, N. C., Rowland, J. L., McCoy, J. M., Worrall, L. J., Santos, A. S., Strynadka, N. C. J., and Finlay, B. B. 2017. Assembly, structure, function and regulation of type III secretion systems. Nat. Rev. Microbiol. 15:323-337.

Deslandes, L., Olivier, J., Peeters, N., Feng, D. X., Khounlotham, M., Boucher, C., Somssich, I., Genin, S., and Marco, Y. 2003. Physical interaction between RRS1-R, a protein conferring resistance to bacterial wilt, and PopP2, a type III effector targeted to the plant nucleus. Proc. Natl. Acad. Sci. U.S.A. 100:8024-8029.

Desvaux, M., Hébraud, M., Talon, R., and Henderson, I. R. 2009. Secretion and subcellular localizations of bacterial proteins: A semantic awareness issue. Trends Microbiol. 17:139-145.

Dillon, M. M., Almeida, R. N. D., Laflamme, B., Martel, A., Weir, B. S. Desveaux, D., and Guttman, D. S. 2019. Molecular Evolution of Pseudomonas syringae type III secreted effector proteins. Front. Plant Sci. 10:418.

Ditta, G., Stanfield, S., Corbin, D., and Helinski, D. R. 1980. Broad host range DNA cloning system for gram-negative bacteria: Construction of a gene bank of Rhizobium meliloti. Proc. Natl. Acad. Sci. U.S.A. 77: 7347-7351.

Edqvist, P. J., Olsson, J., Lavander, M., Sundberg, L., Forsberg, A., WolfWatz, H., and Lloyd, S. A. 2003. YscP and YscU regulate substrate specificity of the Yersinia type III secretion system. J. Bacteriol. 185: 2259-2266.

Erhardt, M., Singer, H. M., Wee, D. H., Keener, J. P., and Hughes, K. T. 2011. An infrequent molecular ruler controls flagellar hook length in Salmonella enterica. EMBO J. 30:2948-2961.

Feldman, M. F., and Cornelis, G. R. 2003. The multitalented type III chaperones: All you can do with 15 kDa. FEMS Microbiol. Lett. 219: 151-158.

Frachon, L., Libourel, C., Villoutreix, R., Carrère, S., Glorieux, C., HuardChauveau, C., Navascués, M., Gay, L., Vitalis, R., Baron, E., Amsellem, L., Bouchez, O., Vidal, M., Le Corre, V., Roby, D., Bergelson, J., and Roux, F. 2017. Intermediate degrees of synergistic pleiotropy drive adaptive evolution in ecological time. Nat. Ecol. Evol. 1:1551-1561.

Galán, J. E., Lara-Tejero, M., Marlovits, T. C., and Wagner, S. 2014 Bacterial type III secretion systems: Specialized nanomachines for protein delivery into target cells. Annu. Rev. Microbiol. 68:415-438.

Genin, S. 2010. Molecular traits controlling host range and adaptation to plants in Ralstonia solanacearum. New Phytol. 187:920-928.

Gietz, R. D. 2014. Yeast transformation by the LiAc/SS carrier DNA/PEG method. Methods Mol. Biol. 1205:1-12.

Green, E. R., and Mecsas, J. 2016. Bacterial secretion systems: An overview. Microbiol. Spectr. 4.

Haapalainen, M., Engelhardt, S., Küfner, I., Li, C.-M., Nürnberger, T., Lee, J., Romantschuk, M., and Taira, S. 2011. Functional mapping of harpin HrpZ of Pseudomonas syringae reveals the sites responsible for protein oligomerization, lipid interactions and plant defence induction. Mol Plant Pathol. 12:151-166

Hartmann, N., Schulz, S., Lorenz, C., Fraas, S., Hause, G., and Büttner, D. 2012. Characterization of HrpB2 from Xanthomonas campestris pv. vesicatoria identifies protein regions that are essential for type III secretion pilus formation. Microbiology 158:1334-1349.

Heidrich, K., Wirthmueller, L., Tasset, C., Pouzet, C., Deslandes, L., and Parker, J. E. 2011. Arabidopsis EDS1 connects pathogen effector recognition to cell compartment-specific immune responses. Science 334:1401-1404.

Hu, Y., Huang, H., Cheng, X., Shu, X., White, A. P., Stavrinides, J., Köster, W., Zhu, G., Zhao, Z., and Wang, Y. 2017. A global survey of bacterial type III secretion systems and their effectors. Environ. Microbiol. 19: 3879-3895.

Huard-Chauveau, C., Perchepied, L., Debieu, M., Rivas, S., Kroj, T., Kars, I., Bergelson, J., Roux, F., and Roby, D. 2013. An atypical kinase under balancing selection confers broad-spectrum disease resistance in Arabidopsis. PLoS Genet. 9:e1003766.

Hueck, C. J. 1998. Type III protein secretion systems in bacterial pathogens of animals and plants. Microbiol. Mol. Biol. Rev. 62:379-433.

Iakovidis, M., Teixeira, P. J. P. L., Exposito-Alonso, M., Cowper, M. G., Law, T. F., Liu, Q., Vu, M. C., Dang, T. M., Corwin, J. A., Weigel, D. Dangl, J. L., and Grant, S. R. 2016. Effector-triggered immune response in Arabidopsis thaliana is a quantitative trait. Genetics 204:337-353.

Izoré, T., Job, V., and Dessen, A. 2011. Biogenesis, regulation, and targeting of the type III secretion system. Structure 19:603-612.

Journet, L., Agrain, C., Broz, P., and Cornelis, G. R. 2003. The needle length of bacterial injectisomes is determined by a molecular ruler. Science 302:1757-1760.

Kang, H. M., Sul, J. H., Service, S. K., Zaitlen, N. A., Kong, S.-Y., Freimer, N. B., Sabatti, C., and Eskin, E. 2010. Variance component model to account for sample structure in genome-wide association studies. Nat Genet. 42:348-354.

Khan, M., Subramaniam, R., and Desveaux, D. 2016. Of guards, decoys, baits and traps: Pathogen perception in plants by type III effector sensors. Curr. Opin. Microbiol. 29:49-55.

King, E. O., Ward, M. K., and Raney, D. E. 1954. Two simple media for the demonstration of pyocyanin and fluorescin. J. Lab. Clin. Med. 44 301-307.

Kvitko, B. H., Ramos, A. R., Morello, J. E., Oh, H.-S., and Collmer, A 2007. Identification of harpins in Pseudomonas syringae pv. tomato DC3000, which are functionally similar to HrpK1 in promoting translocation of type III secretion system effectors. J. Bacteriol. 189: 8059-8072.

Lavie, M., Shillington, E., Eguiluz, C., Grimsley, N., and Boucher, C. 2002. PopP1, a new member of the YopJ/AvrRxv family of type III effector proteins, acts as a host-specificity factor and modulates aggressiveness of Ralstonia solanacearum. Mol. Plant-Microbe Interact. 15:1058-1068.

Li, J.-G., Liu, H.-X., Cao, J., Chen, L.-F., Gu, C., Allen, C., and Guo, J.-H 2010. PopW of Ralstonia solanacearum, a new two-domain harpin targeting the plant cell wall. Mol. Plant Pathol. 11:371-381.

Lohou, D., Lonjon, F., Genin, S., and Vailleau, F. 2013. Type III chaperones \& Co in bacterial plant pathogens: A set of specialized bodyguards mediating effector delivery. Front. Plant Sci. 4:435.

Lohou, D., Turner, M., Lonjon, F., Cazalé, A.-C., Peeters, N., Genin, S., and Vailleau, F. 2014. HpaP modulates type III effector secretion in Ralstonia solanacearum and harbours a substrate specificity switch domain essential for virulence. Mol. Plant Pathol. 15:601-614.

Lonjon, F., Lohou, D., Cazalé, A.-C., Büttner, D., Ribeiro, B. G., Péanne, C., Genin, S., and Vailleau, F. 2017. HpaB-dependent secretion of type III effectors in the plant pathogens Ralstonia solanacearum and Xanthomonas campestris pv. vesicatoria. Sci. Rep. 7:4879.

Lonjon, F., Peeters, N., Genin, S., and Vailleau, F. 2018. In vitro and in vivo secretion/translocation assays to identify novel Ralstonia solanacearum type 3 effectors. Pages 209-222 in: Host-Pathogen Interactions. C. Medina and F. López-Baena, eds. Methods in Molecular Biology, vol. 1734. Humana Press, New York, NY, U.S.A

Lonjon, F., Turner, M., Henry, C., Rengel, D., Lohou, D., van de Kerkhove, Q., Cazalé, A.-C., Peeters, N., Genin, S., and Vailleau, F. 2016. Comparative secretome analysis of Ralstonia solanacearum type 3 secretion-associated mutants reveals a fine control of effector delivery, essential for bacterial pathogenicity. Mol. Cell. Proteomics 15:598-613.

Lorenz, C., and Büttner, D. 2011. Secretion of early and late substrates of the type III secretion system from Xanthomonas is controlled by $\mathrm{HpaC}$ and the C-terminal domain of HrcU. Mol. Microbiol. 79:447-467.

Lorenz, C., Schulz, S., Wolsch, T., Rossier, O., Bonas, U., and Büttner, D. 2008. HpaC controls substrate specificity of the Xanthomonas type III secretion system. PLoS Pathog. 4:e1000094

Macho, A. P. 2016. Subversion of plant cellular functions by bacterial typeIII effectors: Beyond suppression of immunity. New Phytol. 210:51-57.

Macnab, R. M. 2003. How bacteria assemble flagella. Annu. Rev. Microbiol. 57:77-100. 
Matsumoto, H., and Young, G. M. 2009. Translocated effectors of Yersinia. Curr. Opin. Microbiol. 12:94-100.

Meyer, D., Cunnac, S., Guéneron, M., Declercq, C., Van Gijsegem, F., Lauber, E., Boucher, C., and Arlat, M. 2006. PopF1 and PopF2, two proteins secreted by the type III protein secretion system of Ralstonia solanacearum, are translocators belonging to the HrpF/NopX family. J. Bacteriol. 188:4903-4917.

Molina, I., and Kosma, D. 2015. Role of HXXXD-motif/BAHD acyltransferases in the biosynthesis of extracellular lipids. Plant Cell Rep. 34:587-601.

Morel, A., Guinard, J., Lonjon, F., Sujeeun, L., Barberis, P., Genin, S., Vailleau, F., Daunay, M.-C., Dintinger, J., Poussier, S., Peeters, N., and Wicker, E. 2018. The eggplant AG91-25 recognizes the Type III-secreted effector RipAX2 to trigger resistance to bacterial wilt (Ralstonia solanacearum species complex). Mol. Plant Pathol. 19:2459-2472.

Morello, J. E., and Collmer, A. 2009. Pseudomonas syringae HrpP Is a type III secretion substrate specificity switch domain protein that is translocated into plant cells but functions atypically for a substrateswitching protein. J. Bacteriol. 191:3120-3131.

Nahar, K., Matsumoto, I., Taguchi, F., Inagaki, Y., Yamamoto, M., Toyoda, K., Shiraishi, T., Ichinose, Y., and Mukaihara, T. 2014. Ralstonia solanacearum type III secretion system effector Rip36 induces a hypersensitive response in the nonhost wild eggplant Solanum torvum. Mol. Plant Pathol. 15:297-303.

Parsot, C., Hamiaux, C., and Page, A.-L. 2003. The various and varying roles of specific chaperones in type III secretion systems. Curr. Opin. Microbiol. 6:7-14.

Peeters, N., Carrère, S., Anisimova, M., Plener, L., Cazalé, A.-C., and Genin, S. 2013a. Repertoire, unified nomenclature and evolution of the Type III effector gene set in the Ralstonia solanacearum species complex. BMC Genomics 14:859.

Peeters, N., Guidot, A., Vailleau, F., and Valls, M. 2013b. Ralstonia solanacearum, a widespread bacterial plant pathogen in the postgenomic era. Mol. Plant Pathol. 14:651-662.

Perrier, A., Barberis, P., and Genin, S. 2018. Introduction of genetic material in Ralstonia solanacearum through natural transformation and conjugation. Pages 201-207 in: Host-Pathogen Interactions. C. Medina and F. López-Baena, eds. Methods in Molecular Biology, vol. 1734. Humana Press, New York, NY, U.S.A.

Platt, A., Horton, M., Huang, Y. S., Li, Y., Anastasio, A. E., Mulyati, N. W., Agren, J., Bossdorf, O., Byers, D., Donohue, K., Dunning, M., Holub, E. B., Hudson, A., Le Corre, V., Loudet, O., Roux, F., Warthmann, N., Weigel, D., Rivero, L., Scholl, R., Nordborg, M., Bergelson, J., and Borevitz, J. O. 2010. The scale of population structure in Arabidopsis thaliana. PLoS Genet. 6:e1000843.

Plener, L., Manfredi, P., Valls, M., and Genin, S. 2010. PrhG, a transcriptional regulator responding to growth conditions, is involved in the control of the type III secretion system regulon in Ralstonia solanacearum. J. Bacteriol. 192:1011-1019.

Popa, C. M., Tabuchi, M., and Valls, M. 2016. Modification of bacterial effector proteins inside eukaryotic host cells. Front. Cell. Infect. Microbiol. 6:73.

Poueymiro, M., Cunnac, S., Barberis, P., Deslandes, L., Peeters, N., CazaleNoel, A.-C., Boucher, C., and Genin, S. 2009. Two type III secretion system effectors from Ralstonia solanacearum GMI1000 determine hostrange specificity on tobacco. Mol. Plant-Microbe Interact. 22:538-550.

Raffaele, S., Leger, A., and Roby, D. 2009. Very long chain fatty acid and lipid signaling in the response of plants to pathogens. Plant Signal. Behav. 4:94-99.

Raffaele, S., Vailleau, F., Léger, A., Joubès, J., Miersch, O., Huard, C., Blée, E., Mongrand, S., Domergue, F., and Roby, D. 2008. A MYB transcription factor regulates very-long-chain fatty acid biosynthesis for activation of the hypersensitive cell death response in Arabidopsis. Plant Cell 20:752-767.

Rohart, F., Gautier, B., Singh, A., and Lê Cao, K.-A. 2017. mixOmics: An R package for 'omics feature selection and multiple data integration. PLOS Comput. Biol. 13:e1005752.

Roux, B., Bolot, S., Guy, E., Denancé, N., Lautier, M., Jardinaud, M.-F., Fischer-Le Saux, M., Portier, P., Jacques, M.-A., Gagnevin, L., Pruvost, O., Lauber, E., Arlat, M., Carrère, S., Koebnik, R., and Noël, L. D. 2015. Genomics and transcriptomics of Xanthomonas campestris species challenge the concept of core type III effectome. BMC Genomics 16:975.

Slowikowski, K. 2019. ggrepel: Automatically position non-overlapping text labels with 'ggplot2'. R package version 0.8.1. https://cran.rproject.org/web/packages/ggrepel/index.html

Thomas, W. J., Thireault, C. A., Kimbrel, J. A., and Chang, J. H. 2009. Recombineering and stable integration of the Pseudomonas syringae pv. syringae $61 \mathrm{hrp} / \mathrm{hrc}$ cluster into the genome of the soil bacterium Pseudomonas fluorescens Pf0-1. Plant J. 60:919-928.

Wenk, M. R. 2006. Lipidomics of host-pathogen interactions. FEBS Lett. 580:5541-5551.

Wickham, H. 2017. tidyverse: Easily install and load the 'Tidyverse'. R package version 1.2.1. https://cran.r-project.org/web/packages/tidyverse/index.html

Withers, J., and Dong, X. 2017. Post-translational regulation of plant immunity. Curr. Opin. Plant Biol. 38:124-132.

Wood, S. E., Jin, J., and Lloyd, S. A. 2008. YscP and YscU switch the substrate specificity of the Yersinia type III secretion system by regulating export of the inner rod protein YscI. J. Bacteriol. 190:4252-4262.

Zarivach, R., Deng, W., Vuckovic, M., Felise, H. B., Nguyen, H. V., Miller, S. I., Finlay, B. B., and Strynadka, N. C. J. 2008. Structural analysis of the essential self-cleaving type III secretion proteins EscU and SpaS. Nature 453:124-127.

Zheng, Z., Qualley, A., Fan, B., Dudareva, N., and Chen, Z. 2009. An important role of a BAHD acyl transferase-like protein in plant innate immunity. Plant J. 57:1040-1053. 